\title{
BONJOUR ET ADIEU
}

In Bonjour, Monsieur Courbet the artist, rucksack on back and staff in hand, encounters a gentleman dressed in his Sunday best, with servant and dog, blocking his way on a country road. The resolute beard, the chance meeting and sense of an unfinished journey, come together in my memory of Malcolm. I had been a contributor to TEMPO in the seventies under David Drew. After returning to New Zealand in 2002, feeling disconnected from the mainstream, I began sending Malcolm an article or two and was made to feel welcome. Around 2006, thinking he might be able to use another pair of eyes, but mostly as a ploy to stay connected, I volunteered to help as an informal proofreader. Thanks to email and a shared sense of mission, we remained in touch for some eight years. He never complained.

A good editor is like a camera lens on which we rely for a clear and focused view, and for breadth of view as well. I shared Malcolm's interest in Schoenberg and Varèse, and came to admire his enthusiasm for neglected figures like John Foulds, as I had previously been persuaded to share David Drew's sympathy for Kurt Weill and Walter Leigh.

For a student of new music in the early sixties in New Zealand, $T E M P O$ set the standard and provided a lifeline of news and information to these remote parts. I owe a great deal to its friendship. When I first settled in London, Colin Mason offered me my first assignments as a lowly concert reviewer for the Daily Telegraph. Soon after, when David Drew took over the editorship of TEMPO, he was kindness itself, and under his patient guidance my writing began to take shape. By the time Malcolm joined, I was helping John M. Thomson with the first issues of Early Music, only to discover that early and avant-garde music were two faces of the same coin, and could learn from one another.

Perhaps we may have met as juniors early on in the upstairs office at Boosey \& Hawkes, I cannot remember. As far as I recall, we met face to face only once, very recently, sometime in May 2009. I had come to Bristol to see family following a lacklustre conference in Barcelona and wanted to see him. I would have hired a car, but he insisted on taking the train to meet me in Bristol. He looked ravenous, was thin as a rake, bearded, bright-eyed, like Courbet's Scholar Gipsy or Chaucer's Clerk of Oxenford. Grabbing my arm, he steered me to a favourite café for a late breakfast of sausage, egg, and baked beans on toast over a mug of strong tea.

From where I sit, a single encounter is all and everything. The presence remains, the conversation momentarily interrupted.

Robin Maconie 